\title{
TARDIVE DYSKINESIA AND OTHER EXTRAPYRAMIDAL SYMPTOMS ASSOCIATED WITH ARIPIPRAZOLE: A CASE SERIES
}

\author{
Nayana Sanjay Naik1, Yvonne Da Silva Pereira², Prashant Gohil ${ }^{3}$ \\ ${ }^{1}$ Assistant Professor, Institute of Psychiatry and Human Behaviour, Bambolim, Goa. \\ ${ }^{2}$ Professor and HOD, Institute of Psychiatry and Human Behaviour, Bambolim, Goa. \\ 3 Post Graduate Student, Institute of Psychiatry and Human Behaviour, Bambolim, Goa.
}

\begin{abstract}
\section{BACKGROUND}

Aripiprazole is a third generation antipsychotic introduced in 2004 for treatment of Schizophrenia and bipolar disorders. It has partial agonist activity at dopamine D2 receptor and D2 antagonist activity under hyperdopaminergic condition. In addition, it is a partial agonist at serotonin 5HT1A receptor and antagonist at 5HT2A receptor. Because its pharmacological profile differs from other atypical antipsychotics, it was initially thought to produce lesser side effects and movement disorders. But over the years, there is a growing body of evidence in the form of case reports and case series of Aripiprazole induced movement disorders like Tardive dyskinesia, Parkinsonism, akathisia and dystonia. Of late it has been advocated for irritability associated with autism and as an augmenter for depressive disorder. It has lower potential for weight gain and sedation, as it has relatively low affinity for $\mathrm{H}_{1}$ [Histamine] receptor compared to clozapine, olanzapine and quetiapine. Based on this unique mechanism, it is claimed to have minimal or non-significant motor side effects like Tardive dyskinesia. We document a case series of 8 patients who developed Tardive dyskinesia, Parkinsonism and akathisia following treatment with Aripiprazole (ARP).
\end{abstract}

\section{METHODS}

This is both retrospective and observational study. Patients from outpatient and inpatient department of a tertiary psychiatric teaching hospital with an ICD-10 diagnosis of psychiatric disorder, who has experienced movement disorder while on treatment with Aripiprazole are included in this report. All these patients were under the care of authors as treating Psychiatrists. Rating scales like Abnormal Involuntary Movement Scale (AIMS), Naranjo's Causality Scale, Barnes Akathisia Rating Scale (BARS) and Simpson Angus extrapyramidal Scale (SAS) were used.

\section{RESULTS}

Total of eight patients presented with various movement disorders associated with Aripiprazole, out of which three patients with tardive dyskinesia, three with akathisia and two with Parkinsonism. Patient with tardive dyskinesia showed partial improvement in symptoms after necessary intervention. Patients with akathisia improved completely after stopping ARP, whereas one patient presented with Parkinsonism was diagnosed as Parkinson's disease, improved completely with antiparkinsonian drugs.

\section{CONCLUSIONS}

Off label use of Aripiprazole is on the rise due to its potency and better side effect profile as compared to first generation antipsychotics. However, it is not free from extrapyramidal side effect as thought earlier. Clinician needs to be vigilant about emerging side effect of movement disorder, especially potentially irreversible like Tardive dyskinesia when prescribing the drug.

\section{KEYWORDS}

Aripiprazole, Tardive Dyskinesia, Movement Disorder.

HOW TO CITE THIS ARTICLE: Naik NS, Pereira YDS, Gohil P. Tardive dyskinesia and other extrapyramidal symptoms associated with aripiprazole: a case series. J. Evolution Med. Dent. Sci. 2016;5(50):3229-3235, DOI: 10.14260/jemds/2016/749

\section{INTRODUCTION}

Tardive Dyskinesia (TD) is an iatrogenic movement disorder of various phenomenologies which has delayed onset, caused by Dopamine Receptor-Blocking Agents (DRBA), also called neuroleptics. Phenothiazines, the First Generation Antipsychotics (FGA's) were introduced in early 1950's, revolutionized the treatment of schizophrenia and other psychosis. However, a few years later these neuroleptics were

Financial or Other, Competing Interest: None.

Submission 05-05-2016, Peer Review 30-05-2016,

Acceptance 06-06-2016, Published 23-06-2016.

Corresponding Author:

Dr. Nayana Sanjay Naik,

BFF 41 "OM-HARI" Housing Society,

Goa Housing Board,

Alto Porvorim Bardez-403521,

Goa, India

E-mail: nnaik2002@yahoo.co.in

DOI: $10.14260 /$ jemds $/ 2016 / 749$ recognized as a cause of abnormal involuntary movements. Schonecker M (1957) reported case of a patient, treated with Phenothiazine derivative, megaphen, developed orofacial stereotypic involuntary movements referred to as "paroxysmal dyskinesia".[1] Theoretically, second generation or atypical antipsychotics produces lower incidence of extrapyramidal symptoms and metabolic side effects. According to the Diagnostic and Statistical Manual of Mental Disorders, 4th ed. (DSM-IV), signs and symptoms of neuroleptic induced TD develops during exposure to neuroleptic medications or within 4 weeks of withdrawal from an oral medication (Or within 8 weeks of withdrawal from a depot medication. There must be history of use of neuroleptic medications for at least 3 months (Or 1 month in patient aged 60 years or older).[2] TD is difficult to treat and often irreversible form of dyskinesia. The involuntary movements are tardive, meaning they have a slow and belated onset. The term "Tardive Dyskinesia" (TD) was first introduced in 1964 
by Faurbye, highlighting the delay between the initiation of treatment with the offending drug and the onset of the abnormal movements (Hence, the name "tardive").[3] Dyskinesia is a type of movement disorder that is subdivided into bradykinesias and hyperkinesias. Bradykinesias are characterized by abnormal slowness, rigidity, masked like faces of patients with Parkinson's disease.

Hyperkinesias is purposeless movement including akathisia, tremors, dystonias, myoclonus, chorea and tics. Tardive hyperkinesias are also called Tardive dyskinesias, are isolated involuntary dyskinesia mainly developing in the orofacial region. As a rule just orofacial region is affected, but the limbs are also affected sporadically. Sometimes Tardive Gilles de la Tourette's syndrome, tardive action tremors, postural tremors, tardive rhythmic/arrhythmic muscle contraction in arm often combined with other movement disorder after longer duration of treatment may also be seen. ${ }^{[4]}$

TD is more common in patients with schizophrenia, schizoaffective disorders, bipolar disorders who have been treated with antipsychotics for a long time. People with organic disorder like foetal alcohol syndrome and other developmental disabilities are more prone to development of the TD even after single dose of the causative agent. Other risk factor includes age and female gender, pre-existing Parkinsonism, previous brain damage, antipsychotic treatment duration and exposure to FGAs. Neuroleptic induced TD is excluded if signs and symptoms are due to other neurologic disorder that may involve basal ganglia or medical disorder like hyperthyroidism or due to ill-fitted dentures or other medications like levodopa, amphetamines, metoclopramide. Antiparkinsonism agents generally does not improve neuroleptic induced dyskinesia. Decreasing the dose of neuroleptic may temporarily worsen TD, but in some patients increasing the dose of neuroleptic may reduce symptoms thereby masking the TD.

There are various hypotheses regarding aetiology of TD, but widely accepted hypothesis is chronic blockade of D2 receptor in striatum, which leads to up-regulation of the postsynaptic receptor in the striatum. However, this side effect has been noted to persist chronically even after stopping the causative agent and receptor has been down-regulated to baseline.[5]

As Tardive dyskinesia is frequently associated with first generation neuroleptics, these medications should be used restrictively only in major mental disorder and also doses should be kept low. It is advisable to replace typical with atypical antipsychotics, as they are comparatively safer and more effective. In $40 \%$ of the cases, dyskinesia will spontaneously disappear after stopping or replacing the medication. In other cases tetrabenazine $25-150 \mathrm{mg} /$ day or cholinomimetic medications might be successfully applied, not only in Tardive dyskinesia but also in Tardive tremors.[6] but not anticholinergic agent as they will increase these dyskinesia. ${ }^{[7]}$ Also dopamine agonist bromocriptine, the GABA agonist baclofen, calcium channel blockers and clonazepam might be successful in treatment of this disabling complication of treatment with neuroleptics. Off label use of ARP in various psychotic and non-psychotic conditions is on the rise. Also there is increasing evidence in the form of case reports and meta-analysis on various movement disorders associated with ARP. Some of the earlier studies has compared side effect of ARP to that of placebo. We report a case series of 8 patients, of which 3 with Tardive dyskinesia, 3 patients with acute akathisia and two patients with Parkinsonism associated with use of ARP.

\section{AIMS AND OBJECTIVES}

To draw attention to the growing incidence of Tardive dyskinesia and other movement disorder associated with Aripiprazole.

\section{Inclusion Criteria}

1. Age group 18-70 years.

2. Patient with psychiatric diagnosis based on criteria of $10^{\text {th }}$ revision of International Classification of Diseases (ICD-10).

3. Patients on Aripiprazole for minimum of 15 days' period.

4. Patients under the care of authors as treating Psychiatrist.

\section{Exclusion Criteria}

Patients with substance abuse, severe neurological and medical illness.

\section{Ethical Clearance}

Clearance from Institutional Research Committee was taken to publish the reports. Consent from the patients and primary care giver was taken, where possible to publish the cases.

\section{MATERIAL AND METHODS}

Study Setting: Study was conducted in a tertiary care psychiatric teaching hospital which has Inpatient and Outpatient facilities in north district, State of Goa.

\section{Study Design}

This is both retrospective and observational study of patients undergoing psychiatric treatment at Inpatient and Outpatient clinic. These patients were receiving Aripiprazole for various psychotic disorders, developed Tardive dyskinesia, akathisia and Parkinsonism are included in this report. Data is collected from the structured clinical case record files and the clinical experience of the authors as treating psychiatrists. Patient carried a psychiatric diagnosis based on criteria of $10^{\text {th }}$ revision of International Classification of Diseases (ICD-10).[8] by World Health Organization. Rating Scales for movement disorder were used for severity and to establish the causality for adverse drug reaction. Authors accessed Pubmed, Pubmed Central (PMC), Google scholar and other related articles on the subjects using the key words Aripiprazole, Movement Disorders, Tardive Dyskinesia.

\section{ASSESSMENT TOOLS \\ Following Research Scales were used}

\section{Abnormal Involuntary Movement Scale (AIMS)}

It is 12 items anchored scale that is clinician administered and scored. It is a global rating scale and records the occurrence of Tardive Dyskinesia (TD) in patients receiving neuroleptic medications and to follow the severity of a patient's TD over time. Item 1-10 are rated on a 5-point anchored scale of which item 1-4 assess orofacial movements, item 5-7 deals with extremity and truncal dyskinesia, item 8-10 deal with global severity as judged by the examiner and patient's awareness of the movements and distress associated with them. Item 11-12 are yes-no questions concerning problems with teeth and/or dentures, because such problems can lead to a mistaken diagnosis of dyskinesia. 


\section{Naranjo's Causality Scale}

The Adverse Drug Reaction (ADR) Probability Scale was developed in 1991 by Naranjo.[9] and workers from the University of Toronto and is often referred to as the Naranjo's Scale. This scale was developed to help standardize assessment of causality for all adverse drug reactions. It is simple to apply and widely used. The ADR Probability Scale consists of 10 questions that are answered as either Yes, No or "Do not know." Different point values $(-1,0,+1$ or +2$)$ are assigned to each answer. Total scores range from -4 to +13 ; the reaction is considered definite if the score is 9 or higher, probable if 5 to 8 , possible if 1 to 4 and doubtful if 0 or less.

\section{Barnes Akathisia Rating Scale (BARS). [10]: The Scoring is Done as follows}

Objective akathisia, subjective awareness of restlessness and subjective distress related to restlessness are rated on a 4point scale from $0-3$ and is summed yielding a total score ranging from 0 to 9 . The global Clinical assessment of akathisia uses a 5-point scale ranging from 0-4.

\section{Simpson Angus Extrapyramidal Side Effect Scale[11] (SAS)}

Rating scale used for extrapyramidal side effects. It is a 10item testing instrument used to evaluate drug-related extrapyramidal syndromes. Items in SAS are, Gait, arm dropping, shoulder shaking, elbow rigidity, wrist rigidity, leg pendulousness, head dropping, glabellar tap, tremor, salivation. Range of scores is $0-40$; increased scores indicate increased severity.

\section{RESULTS}

\section{Presentation of Cases}

We present 8 cases of Aripiprazole associated with movement disorder. Three illustrative cases and one from each section is presented below with all cases being summarized in table 1 .

\begin{tabular}{|c|c|c|c|c|c|c|c|c|c|}
\hline $\begin{array}{l}\text { Serial No. } \\
\text { and } \\
\text { Patient }\end{array}$ & Age & Sex & Diagnoses & \begin{tabular}{|c|} 
Years/ \\
Months \\
Since \\
Diagnoses \\
\end{tabular} & $\begin{array}{c}\text { Years/ } \\
\text { Months of TD }\end{array}$ & $\begin{array}{l}\text { Medications } \\
\text { Received }\end{array}$ & TD Signs & $\begin{array}{l}\text { Medications } \\
\text { \& Other } \\
\text { Intervention } \\
\text { for TD } \\
\end{array}$ & Response \\
\hline 1. MK & $\begin{array}{c}55 \\
\text { years }\end{array}$ & $\mathrm{F}$ & $\begin{array}{l}\text { Bipolar } \\
\text { Affective } \\
\text { Disorder }\end{array}$ & 24 Years & 4 Months & $\begin{array}{c}\text { Previously: Lithium, } \\
\text { Valproate, quetiapine, } \\
\text { oxcarbazepine, } \\
\text { Aripiprazole } \\
\text { Currently: } \\
\text { Aripiprazole, } \\
\text { Oxcarazepine, } \\
\text { Clonazepam } \\
\end{array}$ & \begin{tabular}{|} 
Tremors of hand, \\
peri-oral \\
dyskinesia, \\
tongue \\
protrusion \\
blepharospasm
\end{tabular} & $\begin{array}{c}\text { Vitamin-E, } \\
\text { clonazepam } \\
\text { lowered dose of } \\
\text { Aripiprazole }\end{array}$ & $\begin{array}{c}\text { Mild } \\
\text { Improvement } \\
\text { in TD } \\
\text { Symptoms }\end{array}$ \\
\hline 2. AM & $\begin{array}{r}70 \\
\text { yrs. }\end{array}$ & $\mathrm{F}$ & $\begin{array}{c}\text { Dementia with } \\
\text { Psychosis }\end{array}$ & 21/2 Years & 2 Years & $\begin{array}{l}\text { Donepezil, } \\
\text { Aripiprazole, } \\
\text { Divalproex } \\
\text { sodium }\end{array}$ & $\begin{array}{l}\text { Orofacial } \\
\text { dyskinesia, } \\
\text { tremors of } \\
\text { hand }\end{array}$ & $\begin{array}{c}\text { Stopped } \\
\text { Aripiprazole. } \\
\text { Vitamin-E } 800 \\
\text { mg/day initiated }\end{array}$ & \begin{tabular}{|c|} 
Minimal \\
improvement \\
in Hand \\
tremors. \\
Orofacial \\
dyskinesia \\
persistent.
\end{tabular} \\
\hline 3. ND & $\begin{array}{c}61 \\
\text { yrs. }\end{array}$ & $\mathrm{F}$ & $\begin{array}{l}\text { Unspecified } \\
\text { Psychosis }\end{array}$ & 6 Months & 2 Months & $\begin{array}{c}\text { Quetiapine, } \\
\text { Aripiprazole, } \\
\text { Trihexyphenidyl }\end{array}$ & \begin{tabular}{|} 
Upper limbs \\
tremors, perioral \\
tremors, tongue \\
protrusion
\end{tabular} & $\begin{array}{c}\text { Aripiprazole } \\
\text { stopped and } \\
\text { quetiapine } \\
\text { continued. } \\
\text { Vitamin-E, } 800 \\
\text { mg/day added }\end{array}$ & \begin{tabular}{|c|} 
Orofacial \\
tremors \\
persisted. Mild \\
improvement \\
in upper limb \\
tremors noted.
\end{tabular} \\
\hline $\begin{array}{l}\text { Sr. No. } \\
\text { and } \\
\text { Patient }\end{array}$ & Age & Sex & Diagnoses & $\begin{array}{l}\text { Years/ } \\
\text { Months } \\
\text { Since } \\
\text { Diagnoses } \\
\end{array}$ & $\begin{array}{c}\text { Years/ } \\
\text { Months of } \\
\text { Parkinsonism }\end{array}$ & $\begin{array}{l}\text { Medications } \\
\text { received }\end{array}$ & $\begin{array}{l}\text { Parkinsonism } \\
\text { signs }\end{array}$ & $\begin{array}{c}\text { Medications \& } \\
\text { other } \\
\text { intervention for } \\
\text { parkinsonism }\end{array}$ & Response \\
\hline 4. $\mathrm{RN}$ & $\begin{array}{c}62 \\
\text { yrs. }\end{array}$ & M & \begin{tabular}{|} 
Dementia with \\
Psychotic \\
Symptoms
\end{tabular} & 6 Months & 3 Months & $\begin{array}{c}\text { Donepezil, } \\
\text { Aripiprazole, } \\
\text { Trihexyphenidyl }\end{array}$ & $\begin{array}{l}\text { Rigidity, tremors, } \\
\text { drooling of saliva, } \\
\text { stooped posture }\end{array}$ & $\begin{array}{c}\text { L-Dopa, } \\
\text { Ropinirole } \\
\text { started. Stopped } \\
\text { Aripiprazole. } \\
\text { Quetiapine } \\
\text { started. }\end{array}$ & EPS subsided \\
\hline 5. NS & $\begin{array}{c}38 \\
\text { yrs. }\end{array}$ & $\mathrm{F}$ & $\begin{array}{c}\text { Paranoid } \\
\text { Schizophrenia }\end{array}$ & 1 Year & 2 Months & $\begin{array}{c}\text { Aripiprazole, } \\
\text { Lorazepam }\end{array}$ & $\begin{array}{c}\text { Marked rigidity, } \\
\text { loss of associated } \\
\text { movement of } \\
\text { arms }\end{array}$ & $\begin{array}{l}\text { Trihexyphenidyl } \\
\text { added. } \\
\text { Reduced dose of } \\
\text { Aripiprazole. }\end{array}$ & EPS resolved \\
\hline $\begin{array}{l}\text { Sr. No. } \\
\text { and } \\
\text { Patient }\end{array}$ & age & Sex & Diagnoses & $\begin{array}{l}\text { Years/ } \\
\text { Months } \\
\text { Since } \\
\text { Diagnoses } \\
\end{array}$ & $\begin{array}{l}\text { Years/ } \\
\text { Months of } \\
\text { Akathisia }\end{array}$ & $\begin{array}{l}\text { Medications } \\
\text { received }\end{array}$ & Akathisia signs & $\begin{array}{c}\text { Medications \& } \\
\text { other } \\
\text { intervention for } \\
\text { akathisia }\end{array}$ & Response \\
\hline 6. LK & $\begin{array}{c}40 \\
\text { yrs. }\end{array}$ & $\mathrm{F}$ & $\begin{array}{l}\text { Depression } \\
\text { with } \\
\text { Psychotic } \\
\text { Features }\end{array}$ & 3 Years & 1 Month & $\begin{array}{l}\text { Olanzapine, } \\
\text { Fluoxetine, } \\
\text { Aripiprazole, } \\
\text { Amisulpride }\end{array}$ & \begin{tabular}{|} 
Restlessness in \\
the legs, anxiety, \\
difficulty in \\
working, inner \\
restlessness \\
\end{tabular} & $\begin{array}{c}\text { Stopped } \\
\text { Aripiprazole }\end{array}$ & $\begin{array}{l}\text { Akathisia } \\
\text { Resolved }\end{array}$ \\
\hline 7. SK & $\begin{array}{c}22 \\
\text { yrs. }\end{array}$ & M & Schizophrenia & 8 Months & 15 Days & $\begin{array}{l}\text { Olanzapine, } \\
\text { Aripiprazole }\end{array}$ & \begin{tabular}{|c} 
Inner feeling of \\
restlessness, urge \\
to move \\
continuously, \\
irritability, \\
tremors. \\
\end{tabular} & $\begin{array}{c}\text { Stopped } \\
\text { Aripiprazole }\end{array}$ & $\begin{array}{l}\text { Akathisia } \\
\text { Resolved }\end{array}$ \\
\hline
\end{tabular}




\begin{tabular}{|c|c|c|c|c|c|c|c|c|}
\hline 8. TB & $\begin{array}{c}43 \\
\text { yrs. }\end{array}$ & F & $\begin{array}{c}\text { Paranoid } \\
\text { Schizophrenia }\end{array}$ & 8 Years & 1 Month & $\begin{array}{c}\text { Aripiprazole, } \\
\text { Lorazepam }\end{array}$ & $\begin{array}{c}\text { Pain in the legs, } \\
\text { nner restlessness, } \\
\text { difficulty in } \\
\text { household work, } \\
\text { wringing of hands. }\end{array}$ & $\begin{array}{c}\text { Introduced } \\
\text { trihexyphenidyl. } \\
\text { Reduced dose of } \\
\text { Aripiprazole }\end{array}$ \\
\hline
\end{tabular}

\section{Illustrative Cases}

MK, 55-year-old Indian female with diagnosis of Bipolar Affective Disorder (BPAD), since 1989 received tablets Lithium Carbonate $900 \mathrm{mg} /$ day and was maintaining well till August 2004. Lithium had to be stopped, as she developed hypothyroidism. She was started on tablets Divalproex sodium $900 \mathrm{mg} /$ day, but developed Jaundice within 1 month, hence it was stopped. She was initiated on risperidone $3 \mathrm{mg} /$ day, which was continued for 1 month, but developed severe joint pain, therefore was stopped. In December 2004, she was started on Aripiprazole $15 \mathrm{mg} /$ day, which she continued till May 2006. She developed mild EPS during the course of therapy, hence anticholinergic Trihexyphenidyl (THP) 2 $\mathrm{mg} /$ day was started and dose of Aripiprazole was reduced to $10 \mathrm{mg} /$ day. EPS subsided within couple of weeks; therefore, THP was discontinued. She remained in remission of BPAD symptoms on $10 \mathrm{mg} /$ day of Aripiprazole till July 2012. In the month of August 2012, she presented with depressed cognition, hence Aripiprazole was increased to $20 \mathrm{mg} /$ day and desvenlafaxine $50 \mathrm{mg}$ was added. Within 15 days she developed motor restlessness (Akathisia), blepharospasm of right eye, dryness of mouth and tremors of right leg; hence, Aripiprazole was reduced to $5 \mathrm{mg} /$ day. She showed considerable improvement in her depressed cognition, akathisia and EPS. In the month of September 2012, she was operated for cataract and all her medications were abruptly stopped by an Ophthalmologist. She experienced Acute Manic episode and was hospitalized. She was treated with a course of Electroconvulsive Therapy (ECT), Oxcarbazepine (OXC) 900 $\mathrm{mg} /$ day, Aripiprazole $30 \mathrm{mg} /$ day and quetiapine $800 \mathrm{mg} /$ day. She regained her premorbid state and was maintained on same dose of medications for next 30 months. In the month of July 2015, she developed acute abdominal pain. Abdominal ultrasound revealed fatty liver, $20 \mathrm{~cm}$ in mid-clavicular line, suspected to be quetiapine induced, hence quetiapine was omitted by gastroenterologist. She was put on liver protective and vitamin E $800 \mathrm{mg} /$ day. Once again she developed Acute Manic episode, which required admission. Her basic blood investigations were normal except mild rise in liver transaminases. She was treated with ECT'S, oxcarbazepine $900 \mathrm{mg} /$ day and Aripiprazole $20 \mathrm{mg} /$ day and maintenance ECT's for next 6 months. During OPD followup in February 2016, it was noticed that she has developed TD movement of perioral region in the form of protrusion of tongue, blepharospasm of right eye, twitching movement of right angle of mouth and tremors of right hand little finger. Her Aripiprazole was reduced to $10 \mathrm{mg} /$ day and clonazepam 0.5 $\mathrm{mg} /$ day was added. Currently, she is on oxcarbazepine 900 $\mathrm{mg} /$ day and Vit-E $800 \mathrm{mg} /$ day, Aripiprazole $10 \mathrm{mg} /$ day and clonazepam $0.5 \mathrm{mg} /$ day. There is mild improvement in her TD movement when she reported a month back. Further care plan is to maintain her only on oxcarbazepine $900 \mathrm{mg} /$ day and treat future bipolar episodes with ECT's and oxcarbazepine.

RN, 62 year-old Indian male was brought by relatives in April 2013 with 4 weeks history of excessive talk, fear about children health, ideas of death, disturbed sleep, restless behaviour following argument with his brother. History of hypertension for 7 years, on tablet amlodipine $5 \mathrm{mg} /$ day and occasional forgetfulness was elicited. There was no family history of psychiatric or neurological illness. Also patient did not have any past history of psychiatric or major medical illness.

On examination he was conscious, cooperative, relevant coherent, had nihilistic delusion, referential ideas and depressive ideas secondary to delusions. He reported auditory hallucinations in the form of derogatory comments. His immediate and recent memory was impaired. Folstein's Mini Mental State Examination (MMSE) for cognitive abilities score was 20/30. Physical examination was unremarkable. His CT brain showed prominence of cortical sulci with dilatation of ventricular system suggestive of cortical atrophy. His baseline blood investigations were within normal limits. He was diagnosed as Dementia with psychotic features.

He was started on Donepezil $5 \mathrm{mg} /$ day along with aripiprazole $5 \mathrm{mg} /$ day. Patient was antipsychotic naive, hence aripiprazole was chosen because of better side effect profile compared to other second generation antipsychotics. Over 15 days, dose of aripiprazole was escalated to $15 \mathrm{mg} /$ day. Within next 2 weeks, his psychotic symptoms improved, but he experienced severe Extrapyramidal Symptoms (EPS) in the form of excessive salivation, stooped posture, bradykinesis and masked face, tremors of hands, rigidity and hypersalivation. He scored 30 on Angus scale for extrapyramidal signs, which placed him in severe EPS category. His dose of aripiprazole was reduced to $10 \mathrm{mg} /$ day and trihexyphenidyl $2 \mathrm{mg} /$ day was added. Patient showed good improvement regarding his psychosis; however, even after 4 weeks of reducing the dose of aripiprazole, rigidity did not subside completely and hence neurologist's opinion was sought, wherein he was diagnosed to be having Parkinson's disease dementia. His aripiprazole was stopped and at present he is on carbidopa+levodopa $(10+100)$ combination half tablet three times per day along with tablet Ropinirole $0.5 \mathrm{mg}$ four times a day, tablet Donepezil $10 \mathrm{mg} /$ day and quetiapine 25 $\mathrm{mg} /$ day for occasional auditory hallucinations. His EPS has subsided completely, his cognition has improved considerably and no psychotic features are reported till date.

C: LK, 40-year-old married female was brought to us in August 2014 with severe depression with Psychotic features. Her routine blood investigations, liver function, renal function and thyroid function tests were within normal limits. She was started on Fluoxetine $20 \mathrm{mg} /$ day with Olanzapine $10 \mathrm{mg} /$ day for psychotic symptoms and irritability. Within 4 days she developed oedema of feet, hence Olanzapine was stopped as advised by Physician. Her Fluoxetine was increased to $40 \mathrm{mg}$ per day and she was initiated on $5 \mathrm{mg}$ /day of Aripiprazole for irritability and psychotic symptoms. Within three weeks of starting Aripiprazole she experienced severe restlessness, could not sit at one place, experienced pain in the leg, irritable, could not do household work. Her global score on Barnes Akathisia Rating Scale (BARS) was 4 indicating marked akathisia. Aripiprazole was stopped immediately and 
Clonazepam $0.5 \mathrm{mg}$ twice a day was given. Within a week, her restlessness ameliorated, but her psychotic symptoms persisted hence tablet Amisulpride $50 \mathrm{mg}$ /day was started, which was increased to $100 \mathrm{mg} /$ day. She follows up regularly every month and currently is in remission in terms of depressive and psychotic symptoms.

\section{DISCUSSION}

The prevalence of Aripiprazole-associated TD has been reported to be between 0.2 and $3.4 \%$ in most studies, but some studies states that the incidence of Aripiprazole-induced TD is similar to that of a placebo. Older age, pre-existing movement or neurodegenerative disorders, female gender, the presence of affective illness are the various risk factors for TD mentioned in various studies.

Recently, Pena et al[12] reviewed medical record of patients in Movement Disorder Clinic between 2002 and 2010 to identify patients with TD associated with Aripiprazole. Among 236 patients with TD seen over specified period, 8 (3.4\%) were found to have Aripiprazole associated TD. In 5 patients, TD occurred after exclusive exposure to Aripiprazole. The mean age of onset was $55.8 \pm 26.4$ months with female predominance. Average duration of treatment with Aripiprazole was $18.4 \pm 26.4$ months. In most patients, TD did not spontaneously improve after stopping Aripiprazole.

\section{Case No. 1}

MK, had more than one risk factor. She was on Aripiprazole since 2004. Dose was titrated as and when required with maximum dose up to $30 \mathrm{mg} /$ day in acute phase and a maintenance dose of $10 \mathrm{mg} /$ day during remission phase. Throughout the treatment period with Aripiprazole she would report occasional dystonia, protrusion of tongue and rigidity, which would subside with short course of Trihexyphenidyl. She experienced side effect to other drugs as mentioned earlier, hence was maintained on Aripiprazole (Since 2004) and with oxcarbazepine (Since July 2012). Diagnosis of Oxcarbazepine (OXC) induced dyskinesia was not entertained as dyskinesia is very rare side effect of antiepileptic. In accessed literature, we could find only two cases of OXC induced acute dyskinesia. Herguner M. O. et al (2010).[13] reported an 8-year-old girl with epilepsy on OXC therapy at 15 $\mathrm{mg} / \mathrm{kg}$ daily for 1 week and then $30 \mathrm{mg} / \mathrm{kg} /$ day. Three days after the full dose she was admitted in emergency service with abnormal movement in the form of trismus, tongue protrusion, deviation of the eyes and lateral flexion of the trunk. OXC was stopped and single dose of intravenous diazepam was given and then oral diphenhydramine was given for 2 weeks. Her symptoms stopped in three days. Authors diagnosed her as Tardive dyskinesia.

Bhargava A. et al (2014).[14] reported 11-year-old girl with epilepsy was being treated with OXC developed acute dyskinesia. Probable mechanism suggested by authors is dopamine supersensitivity. In our patient we feel that TD movements were secondary to Aripiprazole, as she would experience acute dyskinesia throughout the course of Aripiprazole therapy and much before OXC initiation. Moreover, this transient dyskinesia would subside with short course of trihexyphenidyl therapy. Interestingly, there is some case report of Aripiprazole relieving TD movements in schizophrenia. Caykoylu et al[15] reported a case where patient developed abnormal movements of the jaw, lips, mouth, tongue and lower extremities developed after escalating dose of risperidone from $4 \mathrm{mg}$ to $6 \mathrm{mg} /$ day. Treatment regime was changed and patient was given Aripiprazole $15 \mathrm{mg} /$ day for next 6 months, which showed improvement in the severity of TD. The authors suggested that the improvement was mediated by partial agonistic activity at the $D_{2}$ receptors and proposed that Aripiprazole be used to treat atypical antipsychotic-induced TD. Osorio et al[16] supported the role of Aripiprazole as an effective treatment for TD. In his patient, the involuntary jaw movement gradually disappeared over a month after starting Aripiprazole $5 \mathrm{mg}$ /day and when the patient stopped treatment TD symptoms re-emerged after 3 months, but disappeared once again when treatment was restarted. However, in these cases, it is difficult to determine whether the improvement was the result of the therapeutic action of Aripiprazole or the effect of withdrawing a highpotency neuroleptic agent.

\section{Case No. 2}

AM, is an elderly lady, apparently naïve to antipsychotics. Her psychotic symptoms ameliorated with of $10 \mathrm{mg}$ Aripiprazole, but developed TD movement within 6 months. She had many of the risk factor like age, neurodegenerative condition (Dementia), and female sex.

\section{Case No. 3}

ND developed Parkinsonism with $350 \mathrm{mg} /$ day of quetiapine; hence, dose of quetiapine was reduced to $300 \mathrm{mg} /$ day and Aripiprazole $10 \mathrm{mg} /$ day was added. But within 1 month she developed TD movement of upper extremity and peri-oral region. Aripiprazole was stopped. Significant improvements in TD movement were noted. She also had many risk factors like age, female sex and neurodegenerative brain condition (Dementia).

All the above three cases of TD did not reverse completely, which draws attention to importance of prevention, early diagnosis and treatment of TD.

\section{Case No. 4}

RN who was antipsychotic naive developed severe parkinsonism with Aripiprazole. He did not show much improvement with anticholinergic drugs and was later diagnosed to be having "Parkinson's disease dementia." Patient who has been or who is currently on antipsychotics developing Parkinsonism, a diagnosis of idiopathic Parkinson's disease is very difficult to make on clinical grounds. However, asymmetrical signs may suggest the development of idiopathic Parkinson's disease in addition to long-standing drug-induced Parkinsonism. It was difficult to diagnose idiopathic Parkinsonism in our patient, as there were no signs of Parkinsonism prior to treatment with Aripiprazole; however, we feel it could be unmasking of Parkinson's disease with Aripiprazole. Treatment with antiparkinsonian drugs like dopamine agonist has been avoided in clinical practice due to their potential to worsen psychosis, but in 2014, Bhandari R and Agarwal A.[17] Presented a case series of 10 patients of drug-induced Parkinsonism, in whom trial of antiparkinsonism medications was given with good effect and particularly there was no deterioration of psychotic symptoms.

Our patient also showed good response to antiparkinsonian agent, Levodopa+Carbidopa, Ropinirole and currently is free from parkinsonian symptoms. Moreover, there is no worsening of Psychosis. 


\section{Case No. 5}

NS, 38-year-old female, was also antipsychotic naïve. She scored high on Naranjo's scale with score of 9 indicating definite causality factor. She improved with lowering of dose of Aripiprazole and adding trihexyphenidyl. Apparently, she did not have any risk factor and showed good response to Aripiprazole in terms of Psychosis, therefore it was continued at $5 \mathrm{mg}$ /day. Currently, she is asymptomatic and follows-up regularly to outpatient department.

\section{Case No. 6}

LK is a case of Depression with Psychotic features presented to us in July 2013. She was receiving Fluoxetine $40 \mathrm{mg} /$ day with $10 \mathrm{mg}$ of Olanzapine in private clinic. Olanzapine was discontinued within a month as she developed edema of feet. Aripiprazole $10 \mathrm{mg} /$ day was added for psychotic features. Within three weeks of starting Aripiprazole, she developed severe akathisia.

Aripiprazole is metabolized by hepatic microsomal enzymes CYP3A4 and CYP2D6. CYP2D6 is inhibited by Fluoxetine and paroxetine, which may in turn inhibit breakdown and thus increase the level of Aripiprazole. Furthermore, the risk of Selective Serotonin Reuptake Inhibitor (SSRI) may be heightened by concomitant use of antipsychotic medications. ${ }^{[18]}$ Our patient may have developed severe akathisia due to increase in blood level of Aripiprazole, due to inhibition of enzyme by Fluoxetine. Her akathisia subsided after stopping Aripiprazole, but her psychotic features were persistent, therefore was started on amisulpride, which was slowly increased to $100 \mathrm{mg} /$ day. Basu and Brar [2006].[19] reported 4 patients of schizoaffective disorder developed akathasia with Aripiprazole. All the patients were on Selective Serotonin Reuptake Inhibitor (SSRI).

\section{Case No. 7}

SK, our seventh patient, a case of schizophrenia, recognized himself the side effect caused by Aripiprazole and stopped the drug before reporting to Psychiatrist. His akathisia subsided completely.

\section{Case No. 8}

TB, 43-year-old lady a case of Paranoid Schizophrenia was asymptomatic on $15 \mathrm{mg}$ of Aripiprazole for 8 years. Recently, it was increased $20 \mathrm{mg} /$ day as she experienced auditory hallucinations, but within 20 days she developed akathisia, hence trihexyphenidyl $2 \mathrm{mg} /$ day was added and dose of Aripiprazole was reduced to $10 \mathrm{mg} /$ day. She showed total improvement in akathisia and there was no worsening of psychosis noted.

\section{CONCLUSION AND IMPLICATION}

With increasing utilization of Aripiprazole for various psychotic and non-psychotic disorders, [Tourette's syndrome, autism, drug resistant depression, etc.], caution should be exercised regarding the emergent side effects like TD, especially in vulnerable population. Before and during the treatment, need for treatment with antipsychotics should be assessed. Throughout the course of therapy re-evaluate the need for continuation of the neuroleptics. In theory, though Aripiprazole is safer than conventional and other second generation antipsychotics, our case series underlines the need for appropriate informed consent, continuous monitoring for emergent side effects because of the ability of Aripiprazole to produce potential irreversible neuromuscular adverse effects. Clinician should be aware of the pharmacokinetics, pharmacodynamics of this molecule and evidence base in terms of psychiatric illness being treated. Also dosing may be for shorter period of time and lowest effective dose on a case by case may be encouraged.

\section{REFERENCES}

1. Schonecker M. Paroxysmal dyskinesia as the effect of megaphen. Nervenarzt 1957;28(12):550-3. Available from:

https://books.google.co.in/books?isbn=110706600X.

2. Washington DC. American Psychiatric Association. Diagnostic and statistical manual of mental disorders, 4 th ed. Text Revision (DSM-IV-TR) 2000:803-5.

3. Faurbye A, Rasch PJ, Petersen PB, et al. Neurological symptoms in pharmacotherapy of psychosis. Acta Psychiatr Scand 1964;40:10-27.

4. Tominaga $H$, Fukuzako $H$, Izumi $K$, et al. Tardive myoclonus. Lancet 1987;1:322. Available from:

https://books.google.co.in/books?isbn=0824750969.

5. Tarsy D. History and definition of tardive dyskinesia. Clin Neuropharmacol 1983;6(2):91-9.

6. Jankovic J, Beach J. Long term effect of tetrabenazine in hyperkinetic movement disorder. Neurology 1997;48(2):358-62.

7. Tamminga CA, Crayton JW, Chase TN. Improvement in tardive dyskinesia after muscimol therapy. Arch Gen Psyiatry 1979;36(5):595-8. Available from: https://books.google.co.in/books?isbn=1468450387.

8. The ICD-10 classification of mental and behavioural disorders, clinical descriptions and diagnostic guidelines. World Health Organization Geneva, 1992.

9. Naranjo CA, Busto U, Seller EM, et al. A method for estimating the probability of adverse drug reactions. Clin Pharmacol Ther 1981;30(2):239-45.

10. Barnes TR. A rating scale for drug induced akathisia. British Journal of Psychiatry 1989;154(5):672-6.

11. Simpson GM, Angus JW. A rating scale for extrapyramidal side effects. Acta Psychiatrica Scandinavica 1970;212:119.

12. Pena MS, Yaltho TC, Jankovic J. Tardive dyskinesia and other movement disorders secondary to aripiprazole. Mov Disord 2011;26(1):147-52.

13. Hergüner MO, Incecik F, Altunbaşak Ş. Oxcarbazepineinduced tardive dyskinesia: a rare adverse reaction. Journal of Paediatric Neurosciences 2010;5(1):85-6.

14. Bhargava A, Bhushan B, Khichar S, et al. Acute dyskinesia: a rare adverse effect of oxcarbazepine in epilepsy with neurobehavioral symptoms. Int J Nutr Pharmacol Neurol Dis 2014;4(1):74-6. Available from: http://www.ijnpnd.com/text.asp?2014/4/1/74/124618

15. Caykoylu A, Ekinci O, Yilmaz E. Resolution of risperidoneinduced tardive dyskinesia with a switch to aripiprazole monotherapy. Prog Neuropsychopharmacol Biol Psychiatry 2009;33(3):571-2.

16. Osorio RS, Ortiz AL, de Mendoza AH, et al. Treatment of tardive dyskinesia with aripiprazole. Neurotox Res 2010;17(4):432-4. 
17. Bhandari R, Aggarwal A. Pharmacotherapy in patients with drug induced parkinsonism: a case series. International Neuropsychiatric Disease Journal 2014;2(3):115-20. Available from: http://sciencedomain.org/download/MzQ1M0BAcGY

18. Gerber PE, Lynd LD. Selective serotonin reuptake inhibitor induced movement disorder. Ann Pharmacother 1998;32(6):692-8.
19. Basu R, Brar J. Dose dependent rapid- onset akathisia with aripiprazole in patients with schizoaffective disorder. Neuropsychiatric Dis Treat 2006;2(2):241-3. 